\title{
ASUMSI DASAR TEORI KOGNITIF, BEHAVIORISTIK DAN HUMANISTIK
}

\author{
I Wayan Karya \\ Institut Agama Hindu Negeri Tampung Penyang Palangkaraya \\ bawiayahfda@gmail.com
}

$\begin{array}{ll}\text { Riwayat Jurnal - } & \\ \text { Artikel diterima } & :- \\ \text { Artikel direvisi } & :- \\ \text { Artikel disetujui } & \text { : - }\end{array}$

\section{Abstrak}

Perkembangan kognitif berhubungan dengan kecerdasan dan pengetahuan. Kecerdasan dan pengetahuan bukan kuantitas atau sesuatu hal yang statis. Kecerdasaan adalah aktif, dinamis dan senantiasa berubah sedangakan pengetahuan adalah mengetahui dan ia adalah sebuah proses yang diciptakan melalui aktivitas pemelajar (Gredler, 2011:325). Hal ini dapat dikatakan bahwa kecerdasan dan pengetahuan seseorang selalu berubah melalui interaksi individu dengan lingkungannya. Dengan demikian interaksi dengan lingkungan sangat memberikan pengaruh yang besar terhadap perkembangan kecerdasan dan pengetahuan individu. Selain itu, Individu dalam menentukan perkembangan kognitifnya dipengaruhi oleh faktor esensial. Faktor esensial itu adalah lingkungan fisik, kematangan, pengaruh sosial, dan proses yang disebut sebagai penyeimbang.

Teori belajar behavioristik ini berorientasi pada hasil yang dapat diukur dan diamati. Pengulangan dan pelatihan digunakan supaya perilaku yang diinginkan dapat menjadi kebiasaan. Hasil yang diharapkan dari penerapan teori behavioristik ini adalah terbentuknya suatu perilaku yang diinginkan. Perilaku yang diinginkan mendapat penguatan positif dan perilaku yang kurang sesuai mendapat penghargaan negatif. Evaluasi atau penilaian didasari atas perilaku yang tampak. Dalam teori belajar ini guru tidak banyak memberikan ceramah, tetapi instruksi singkat yang diikuti contoh baik dilakukan sendiri maupun melalui simulasi.

Menurut aliran humanistik, para pendidik sebaiknya melihat kebutuhan yang lebih tinggi dan merencanakan pendidikan dan kurikukum untuk memenuhi kebutuhankebutuhan ini. Beberapa psikolog humanistik melihat bahwa manusia mempunyai keinginan alami untuk berkembang, untuk lebih baik, dan juga belajar. Jadi sekoah harus berhati-hati supaya tidak membunuh naluri dengan memaksakan anak belajar sesuatu sebelum mereka siap. Jadi bukan hal yang benar apabila anak dipaksa untuk belajar sesuatu sebelum mereka siap secara fisiologis dan juga punya keinginan. Dalam hal ini peran guru adalah sebagai fasilitator yang membantu siswa untuk memenuhi kebutuhan-kebutuhan yang lebih tinggi, bukan sebagai konselor seperti dalam Freudian ataupun pengelola perilaku seperti pada behaviorisme.

Kata Kunci : Kognitif, behavioristik dan humanistik 


\section{Pendahuluan}

Belajar merupakan suatu tindakan dan perilaku siswa yang sangat kompleks dalam mencari dan menerima suatu ilmu pengetahuan. Dalam belajar terdapat interaksi antara guru (pendidik) dengan siswa (peserta didik) untuk mencapai tujuan pembelajaran. Selama ini proses belajar hanya bertumpu kepada pendidik sebagai sumber utama, sehingga peserta didik kurang terlibat dalam pembelajaran, karena peserta didik dikatakan belajar apabila mereka mampu mengingat dan menghafal informasi atau pelajaran yang telah disampaikan. Pembelajaran seperti ini tidak akan membuat peserta didik menjadi aktif, mandiri dan mengembangkan pengetahuannya berdasarkan pengalaman belajar yang telah mereka lakukan. Sedangkan seiring kemajuan zaman dan teknologi, dibutuhkan SDM (Sumber Daya Manusia) dengan karakteristik yang baik. Karakteristik manusia masa depan yang dikehendaki adalah manusia-manusia yang memiliki kepekaan, kemandirian, tanggung jawab terhadap risiko dalam mengambil keputusan, dan mengembangkan segenap aspek potensi melalui proses belajar untuk menemukan diri sendiri dan menjadi diri sendiri.

$$
\text { Langkah strategis bagi }
$$
perwujudan tujuan di atas adalah adanya layanan ahli kependidikan yang berhasil guna dan berdaya guna tinggi, seperti student active learning. Penerapan ajaran tut wuri handayani juga merupakan wujud nyata yang bermakna bagi manusia masa kini dalam rangka menjemput masa depan. Untuk melaksanakannya diperlukan penanganan yang memberikan perhatian terhadap aspek strategis pendekatan yang tepat ketika individu belajar. Kajian terhadap teori belajar kognitif, behavioristik dan teori humanistik dalam kegiatan belajar dan pembelajaran memungkinkan menuju kepada tujuan tersebut.

Perkembangan kognitif berhubungan dengan kecerdasan dan pengetahuan. Kecerdasan dan pengetahuan bukan kuantitas atau sesuatu hal yang statis. Kecerdasan adalah aktif, dinamis dan senantiasa berubah sedangakan pengetahuan adalah mengetahui dan ia adalah sebuah proses yang diciptakan melalui aktivitas pemelajar (Gredler, 2011:325). Hal ini 
dapat dikatakan bahwa kecerdasan dan pengetahuan seseorang selalu berubah melalui interaksi individu dengan lingkungannya. Dengan demikian interaksi dengan lingkungan sangat memberikan pengaruh yang besar terhadap perkembangan kecerdasan dan pengetahuan individu. Selain itu, Individu dalam menentukan perkembangan kognitifnya dipengaruhi oleh faktor esensial. Faktor esensial itu adalah lingkungan fisik, kematangan, pengaruh sosial, dan proses yang disebut sebagai penyeimbang, Piaget, 1977 (dalam Gredler, 2011:327). Dari keempat faktor esensial itu memiliki keterkaitan satu sama lain. Persoalan yang terjadi ketika perkembangan kognitif anak atau individu tidak dapat berkembang secara baik. Hal ini bisa disebabkan oleh banyak faktor, baik itu faktor eksternal maupun internal. Oleh sebab itu kita perlu mempelajari teori perkembangan kognitif agar bisa memahami bagaimana perkembangan kognitif anak atau individu, sehingga kita bisa mengatasi atau menanggulangi hal-hal yang dapat menghabat perkembangan kognitif anak atau individu tersebut.
Teori belajar behavioristik ini berorientasi pada hasil yang dapat diukur dan diamati. Pengulangan dan pelatihan digunakan supaya perilaku yang diinginkan dapat menjadi kebiasaan. Hasil yang diharapkan dari penerapan teori behavioristik ini adalah terbentuknya suatu perilaku yang diinginkan. Perilaku yang diinginkan mendapat penguatan positif dan perilaku yang kurang sesuai mendapat penghargaan negatif. Evaluasi atau penilaian didasari atas perilaku yang tampak. Dalam teori belajar ini guru tidak banyak memberikan ceramah, tetapi instruksi singkat yang diikuti contoh baik dilakukan sendiri maupun melalui simulasi.

Menurut aliran humanistik, para pendidik sebaiknya melihat kebutuhan yang lebih tinggi dan merencanakan pendidikan dan kurikukum untuk memenuhi kebutuhan-kebutuhan ini. Beberapa psikolog humanistik melihat bahwa manusia mempunyai keinginan alami untuk berkembang, untuk lebih baik, dan juga belajar. Jadi sekoah harus berhati-hati supaya tidak membunuh insting ini dengan memaksakan anak belajar sesuatu sebelum mereka siap. Jadi 
bukan hal yang benar apabila anak dipaksa untuk belajar sesuatu sebelum mereka siap secara fisiologis dan juga punya keinginan. Dalam hal ini peran guru adalah sebagai fasilitator yang membantu siswa untuk memenuhi kebutuhan-kebutuhan yang lebih tinggi, bukan sebagai konselor seperti dalam Freudian ataupun pengelola perilaku seperti pada behaviorisme. Secara singkatnya, penedekatan humanistik dalam pendidikan menekankan pada perkembangan positif. Pendekatan yang berfokus pada potensi manusia untuk mencari dan menemukan kemampuan yang mereka punya dan mengembangkan kemampuan tersebut. Hal ini mencakup kemampuan interpersonal sosial dan metode untuk pengembangan diri yang ditujukan untuk memperkaya diri, menikmati keberadaan hidup dan juga masyarakat. Ketrampilan atau kemampuan membangun diri secara positif ini menjadi sangat penting dalam pendidikan karena keterkaitannya dengan keberhasilan akademik.

Teori Humanistik lebih melihat pada sisi perkembangan kepribadian manusia. Pendekatan ini melihat kejadian yaitu bagaimana manusia membangun dirinya untuk melakukan hal-hal yang positif. Kemampuan bertindak positif ini yang disebut sebagai potensi manusia dan para pendidik yang beraliran humanism biasanya memfokuskan pengajarannya pada pembangunan kemampuan positif ini.

\section{Pembahasan}

\subsection{Teori Kognitif}

Menurut Gredler (2011:321) teori kognitif berfokus pada terbentuknya pemikiran manusia pada peringkat tertinggi, serta mendeskripsikan peristiwa dan kondisi yang dibutuhkan untuk mencapai peringkat tersebut. Menurut teori ini, ilmu pengetahuan dibangun dalam diri seorang individu melalui proses interaksi yang berkesinambungan dengan lingkungan. Proses ini tidak berjalan terpisah-pisah, tetap mengalir, dan bersambung-sambung menyeluruh.

Asumsi dasar teori ini adalah setiap orang telah mempunyai pengalaman dan pengetahuan dalam dirinya. Pengalaman dan pengetahuan ini tertata dalam bentuk struktur kognitif. Menurut teori ini proses belajar akan berjalan baik bila materi pelajaran yang baru beradaptasi secara klop dengan 
struktur kognitif yang telah dimiliki oleh siswa.

Piaget mendasarkan investigasinya atas manipulasi dan interaksi individual anak dengan objek di lingkungannya. Fokus dari teori Jean Piaget adalah menemukan asal muasal logika alamiah dan transformasinya dari suatu bentuk penalaran ke penalaran lain. Tujuan ini mengharuskan dilakukannya penelitian atas akar dari pemikiran logis pada bayi, jenis penalaran yang dilakukan anak kecil, dan proses penalaran remaja serta dewasa.

Ada empat faktor yang diperlukan untuk transformasikan perkembangan dari suatu bentuk penalaran ke bentuk yang lain. Faktor itu adalah lingkungan fisik, kematangan, penagruh sosial, dan proses yang disebut sebagai equilibrium (penyeimbangan). Kontak dengan lingkungan fisik merupakan hal penting, karena interaksi antara individu dan dunia adalah sumber ilmu pengetahuan. Namun, kontak itu tidak cukup untuk mengembangkan pengetahuan kecuali individu dapat menggunakan pengalamannya. Namun demikian, kematangan sistem saraf menjadi penting karena memungkinkan anak merealisasikan manfaat maksimum dari pengalaman fisik. Meskipun kematangan merupakan syarat penting untuk perkembangan kognitif, peristiwa perkembangan khusus tidak ditentukan sebelumnya. Perkembangan bergerak dengan kecepatan yang berbeda-beda, tergantung pada sifat kontak anak dengan lingkungan dan pada aktivitasnya.

\subsection{Teori Behavioristik}

Menurut Gredler (1986:42) teori behavioristik (tingkah laku) adalah perubahan tingkah laku sebagai akibat dari interaksi stimulus dan respon. Selanjutnya Gredler (2011:73) juga menjelaskan behaviorisme mendefinisikan belajar sebagai perubahan perilaku dan mengidentifikasi stimuli dan respon spesifik sebagai fokus riset. Pengkondisian klasik menunjukkan bahwa penjajaran stimuli dapat menghubungkan reaksi terhadap stimuli baru. Selain konstribusi untuk psiklogi (deskripsi neuroses dan faktor dalam kecanduan obat), pengkondisian klasik juga membahas aspek-aspek dari situasi sehari-hari Misalnya, bagi anak, rekasi parental yang dipasangkan dengan stimuli asing sering menjadi isyarat bagi rekasi pendekatan atau penghindaran si anak. 
Hari pertama di kelas anak taman kanakkanak dan sekolah dasar, aktivitas yang dilakukan haruslah kegiatan yang dapat menghindari asosiasi kecemasan dan perasaan negatif lainnya terhadap latar sekolah.

Istilah behaviorisme merujuk pada beberapa teori yang mengandung tiga asumsi-asumsi dasar tentang belajar. Asumsi itu adalah:

1. Fokus studi adalah perilaku yang dapat diamati, bukan kejadian mental internal atau rekonstruksi verbal atas kejadian.

2. Perilaku harus dipelajari melalui elemennya yang paling sederhana (stimuli spesifik dan respon spesifik). Contoh reaksi behavioral yang diteliti oleh periset awal antara lain gerak refleks, reaksi emosional yang dapat dilihat, dan respon gerak, dan verbal.

3. Proses belajar adalah perubahan behavioral. Suatu respon khusus terasosiasikan dengan kejadian dari suatu stimulus khusus, dan terjadi dalam kehadiran stimulus tersebut.

4. Skinner mendeksripsikan bahwa peristiwa dan kondisi yang melahirkan pola perilaku. Contohnya adalah merpati yang belajar mematuk dan anak yang belajar membaca. Analisis Skinner mencakup berbagai macam tipe konsekuensi yang memengaruhi perubahan perilaku, efek emosional dari konsekuensi aversif.

Skinner (dalam Gredler, 2011: 118) mendefinisikan belajar sebagai perubahan perilaku. Dalam risetnya, Skinner mendefinisikan variabel terikat sebagai perubahan dalam kemungkinan atau probabilitas dari emitted response. Karena perilaku itu sulit diukur, maka yang diukur terlebih dahulu adalah ratarata atau frekuensi respon yang merupakan langkah awal dalam analisis perubahan perilaku.

Skinner bekerja dengan tiga asumsi dasar, sebagai berikut :

1. Tingkah laku itu mengikuti hukum tertentu (Behavior is lawful). Ilmu adalah usaha untuk menemukan keteraturan, menunjukkan bahwa peristiwa tertentu berhubungan secara teratur dengan peristiwa lain. (Alwisol, 2005:400).

2. Tingkah laku dapat diramalkan (Behavior can be predicted). Ilmu bukan hanya menjelaskan tetapi juga meramalkan. Bukan hanya mengenai peristiwa masa lalu tetapi juga masa 
yang akan datang. Teori yang berdaya guna adalah yang memungkinkan dapat dilakukannya prediksi mengenai tingkah laku yang akan datang dan menguji prediksi itu. (Alwisol, 2005: 400).

3. Tingkah laku dapat dikontrol (Behavior can be controlled). Ilmu dapat melakukan antisipasi dan menentukan/membentuk tingkah laku seseorang. Skinner bukan hanya ingin tau bagaimana terjadinya tingkah laku, tetapi Skinner sangat berkeinginan memanipulasinya (Alwisol, 2005:400401).

Keyakinan Skinner tentang hakikat sekolah dan belajar di kelas menjadi parameter dari teknologi pengajarannya. Sistem pendidikan adalah sangat penting karena kesejahteraan setiap budaya tergantung pada pendidikannya. Namun, karena jumlah siswa yang terus bertambah perhatian personal bagi anak murid jarang ditemukan. Pada saat yang sama, perubahan dalam sistem hanya berupa penyesuaian kecil terhadap situasi yang ada. Contohnya adalah keberadaan "sekolah di dalam sekolah" dibeberapa sekolah menengah pertama dan atas yang besar. Dalam konfigurasiini, kelompokkelompok guru hanya menangani sebagian dari seluruh siswa dan dalam beberapa kasus, mereka mengajar siswa yang sama selama tiga tahun. Kemudian, anak-anak murid juga lebih sering ditugaskan mengerjakan tugas di meja masing-masing padahal mereka dapat berpartisipasi lebih aktif dikelas. Berbagai macam rekomendasi untuk mengatasi masalah edukasional antara lain adalah memperpanjang tahun ajaran dan menyediakan sertifikasi nasional untuk guru.

\subsection{Teori Humanistik}

Teori belajar yang humanistik pada dasarnya memiliki tujuan belajar untuk memanusikan manusia. Oleh karena itu proses belajar dapat dianggap berhasil apabila si pembelajar telah memahami lingkungannya dan dirinya sendiri. Dengan kata lain, si pembelajar dalam proses belajarnya harus berusaha agar lambat laun ia mampu mencapai aktualisasi diri dengan sebaik-baiknya. Tujuan utama para pendidik adalah membantu siswa untuk mengembangkan dirinya, yaitu membantu masing-masing individu untuk mengenal diri mereka sendiri sebagai manusia yang unik dan 
membantu dalam mewujudkan potensipotensi yang ada dalam diri mereka (Sukardjo dan Komarudin, 2009:56).

Rogers memandang manusia sebagai bentuk-bentuk dari konsep dirinya dan pengalaman disatu sisi, dan interpretasinya tentang stimulus lingkungan pada sisi yang lain. Inilah tingkatan kongruensi antara faktor-faktor tersebut yang mempengaruhi perluasan aktualisasi diri yang terjadi. Rogers beragumentasi bahwa perubahanperubahan dalam persepsi diri dan persepsi atas realitas menghasilkan perubahan yang serentak dalam perilaku dan hal itu memberikan kondisi psikologis tertentu bagi seseorang sehingga mempunyai kapasitas untuk mereorganisasi bidang persepsinya, termasuk bagaimana mereka memandang diri mereka sendiri.

Hal yang sangat penting adalah ancaman terhadap konsep diri, sebab diri biasanya menolak memasukkan pengalaman yang tidak konsisten dengan fungsinya. Maka Rogers berpendapat bahwa ketika diri dipandang bebas dari ancaman serangan, maka diri mungkin akan menjawab persepsi yang bertolak dan mengintegrasikannya kembali diri dalam dalam cara yang sedemikian rupa hingga menjadi bagian darinya.

Rogers memiliki pandangan atau asumsi dasar mengenai Humanistik yaitu sebagai berikut :

1. Kecenderungan formatif

2. Segala hal di dunia baik organik maupun non-organik tersusun dari halhal yang lebih kecil.

3. Kecenderungan aktualisasi

4. Kecenderungan setiap makhluk hidup untuk bergerak menuju kesempurnaan atau pemenuhan potensi dirinya. Tiap individual mempunyai kekuatan yang kreatif untuk menyelesaikan masalahnya (Herpratiwi, 2009:50).

Menurut teori di atas, tujuan belajar ialah untuk memanusiakan manusia. Prose belajar dianggap berhasil jika si pelajar telah memahami lingkungannya dan dirinya sendiri. Siswa dalam proses belajarnya harus berusaha agar lambat laun ia mampu mencapai aktualisasi diri dengan sebaik-baiknya. Teori belajar ini berusaha memahami perilaku belajar dari sudut pandang pelakunya, bukan sudut pandang pengamatnya. 


\section{Penutup}

Teori Kognitif yaitu teori pembelajaran yang merupakan penyedia emosional, sosial, fisik dan spiritual. Panduan-panduan tersebut adalah kejelasan informasi yang mendiskripsikan tujuan, pengetahuan yang diperlukan, dan untuk kerjaan itu penting.

Teori

behavioristik

mengutamakan pengukuran, sebab pengukuran merupakan hal yang penting untuk melihat terjadi atau tidaknya perubahan tingkah laku peserta didik. Faktor lain lain yang dianggap penting oleh teori ini adalah faktor reinforcement (penguatan). Bila penguatan ditambahkan maka respon akan semakin kuat.

Aplikasi teori Humanistik lebih menunjuk pada spirit selama proses pembelajaran yang mewarnai metodemetode yang diterapkan. Peran guru dalam pembelajaran Humanistik adalah menjadi fasilitator bagi para siswa sedangkan guru memberikan motivasi, kesadaran mengenai makna belajar dalam kehidupan siswa. Guru memfasilitasi pengalaman belajar kepada siswa dan mendampingi siswa untuk memperoleh tujuan pembelajaran.

\section{Daftar Pustaka}

Alwisol. 2005. Psikologi Kepribadian Edisi Revisi. Malang : UMM Press.

Gredler, R.M. 1996. Learning and Instruction Theory into Practice. New York : McMillan Publishing company.

Gredler, Margaret E. 2011. Learning and Instruction : Teori dan Aplikasi. Eds. VI. Jakarta: Kencana.

Sukardjo dan Komarudin. 2009. Landasan Pendidikan Konsep dan Aplikasinya. Jakarta : Rajawali Press. 